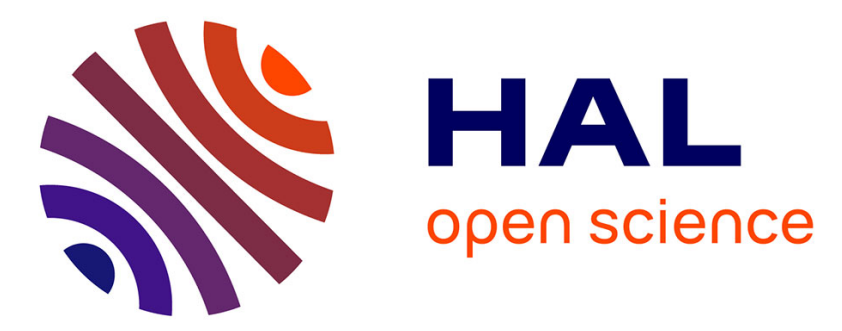

\title{
First estimate of volcanic SO2 budget for Vanuatu island $\operatorname{arc}$
}

\author{
Philipson Bani, Clive Oppenheimer, Patrick Allard, Hiroshi Shinohara, \\ Vitchko Tsanev, Simon Carn, Michel Lardy, Esline Garaebiti
}

\section{To cite this version:}

Philipson Bani, Clive Oppenheimer, Patrick Allard, Hiroshi Shinohara, Vitchko Tsanev, et al.. First estimate of volcanic SO2 budget for Vanuatu island arc. Journal of Volcanology and Geothermal Research, 2012, 211-212, pp.36-46. 10.1016/j.jvolgeores.2011.10.005 . insu-00638268

\section{HAL Id: insu-00638268 \\ https://hal-insu.archives-ouvertes.fr/insu-00638268}

Submitted on 25 Nov 2011

HAL is a multi-disciplinary open access archive for the deposit and dissemination of scientific research documents, whether they are published or not. The documents may come from teaching and research institutions in France or abroad, or from public or private research centers.
L'archive ouverte pluridisciplinaire HAL, est destinée au dépôt et à la diffusion de documents scientifiques de niveau recherche, publiés ou non, émanant des établissements d'enseignement et de recherche français ou étrangers, des laboratoires publics ou privés. 


\title{
First estimate of volcanic $\mathrm{SO}_{2}$ budget for Vanuatu island arc
}

\author{
Philipson Bani ${ }^{\mathrm{a}}$, Clive Oppenheimer ${ }^{\underline{b}, \underline{c}, \underline{d}}$, Patrick Allard $^{\mathrm{e}}$, Hiroshi Shinohara ${ }^{\mathrm{f}}$, \\ Vitchko Tsanev ${ }^{\mathrm{d}}$, Simon Carn ${ }^{\mathrm{g}}$, Michel Lardy ${ }^{\mathrm{a}}$, Esline Garaebiti ${ }^{\mathrm{h}}$
}

a Institut de Recherche pour le Développement, BP A5-98848 NOUMEA Cedex/PPME, Université de la Nouvelle-Calédonie BPR4-98851 Nouméa Cedex, France

${ }^{\mathrm{b}}$ Le Studium, Institute for Advanced Studies, Orléans and Tours, France

${ }^{\mathrm{c}}$ Institut des Sciences de la Terre d'Orléans, 1a rue de la Férollerie, Orléans 45071, France

d Department of Geography, University of Cambridge, Downing Place, Cambridge CB2 3EN, UK

e Institut de Physique du Globe - Sorbonne Paris Cité, GSV, 1 rue Jussieu, 75238 Paris cedex 05, France (also : INGV, Piazza Roma 2, Catania, Italy)

f Geological Survey of Japan, AIST, 1-1-1 Higashi, AIST Central 7, Tsukuba, Ibaraki, 3058567, Japan

g Department of Geological and Mining Engineering and Sciences, Michigan Technological University, Houghton, MI, USA

Vanuatu Meteorological and Geohazards Department, Port-Vila, Vanuatu

\begin{abstract}
The spatial and temporal coverage of measurements of volcanic gas emissions remains patchy. However, over the last decade, emissions inventories have improved thanks to new measurements of some of the lesser-known volcanic areas. We report on one such regionthe Vanuatu island arc, in the Southwest Pacific - for which we now have sufficient systematic observations to offer a systematic emissions inventory. Our new estimate is based on $\mathrm{SO}_{2}$ flux measurements made in the period 2004-2009 with ultraviolet spectroscopy techniques for the following volcanoes: Yasur, Lopevi, Ambrym, Ambae, Gaua and Vanua Lava (from south to north). These are the first ever measurements for Lopevi, Gaua and Vanua Lava. The results reveal the Vanuatu arc as one of Earth's prominent sources of volcanic degassing with a characteristic annual emission to the atmosphere of $\sim 3 \mathrm{Tg}$ of $\mathrm{SO}_{2}$ (representing about $20 \%$ of hitherto published global estimates). Our new dataset highlights the sustained prodigious degassing of Ambrym volcano, whose $5 \mathrm{Gg}_{\text {day }}{ }^{-1}$ mean flux of $\mathrm{SO}_{2}$ represents nearly two-thirds of the total budget for the Vanuatu arc. This confirms Ambrym as one of the largest volcanic sources worldwide comparable to Etna, often considered as the most vigorous source of volcanic emission on Earth. We also report a high degassing for Ambae of $\sim 2 \mathrm{Gg}$ day ${ }^{-1} \mathrm{SO}_{2}$, representing more than $28 \%$ of the Vanuatu arc budget. Thus, $90 \%$ of the $\mathrm{SO}_{2}$ output from Vanuatu is focused in the central part of the arc (from Ambrym and Ambae) where magmas originate from enriched Indian-type mantle and where peculiar tectonic conditions could favor high magma production rates.
\end{abstract}

\section{Introduction}

Sulfur dioxide is a key volcanic gas species for volcano monitoring and for understanding 
the environmental impacts of volcanism at both local and global scales (e.g. Oppenheimer, 2010). In contrast to $\mathrm{H}_{2} \mathrm{O}$ or $\mathrm{CO}_{2}$, the two major components of volcanic gases, which are also abundant atmospheric constituents, $\mathrm{SO}_{2}$ is typically present in rather low abundances in the atmosphere. This, along with its strong ultraviolet and infrared absorption features, makes it comparatively easy to measure remotely with spectroscopic tools. Monitoring temporal variations of $\mathrm{SO}_{2}$ flux at either dormant or erupting volcanoes provides important insights into the presence, size and degassing regimes of magma bodies in the crust (e.g. Allard et al., 1994). In the troposphere, some of the emitted volcanic $\mathrm{SO}_{2}$ is oxidized, mainly in the aqueous phase (with $\mathrm{H}_{2} \mathrm{O}_{2}$ and $\mathrm{O}_{3}$ acting as oxidants), forming acidic sulfate aerosol. Both wet and dry deposition of sulfur species (and associated halogen acid gases) from tropospheric volcanic plumes can have strong impacts on terrestrial and aquatic ecosystems (e.g., [Delmelle et al., 2001] , [Kitayama et al., 2010] and [Martin et al., 2010] ). Finally, huge sulfur releases during major eruptions, whose plumes reach the stratosphere, can strongly affect the atmospheric radiative balance and climate.

Global estimates of volcanic $\mathrm{SO}_{2}$ emissions into the atmosphere are essentially derived from ground-based and space-borne UV spectroscopic measurements, which have been applied to numerous volcanoes and eruptions since the early 1970s ( [Stoiber et al., 1983] , [Andres and Kasgnoc, 1998] and [Halmer et al., 2002] ). Available estimates of global volcanic $\mathrm{SO}_{2}$ emissions range between $13 \mathrm{Tg}_{\text {year }}{ }^{-1}$ (Andres and Kasgnoc, 1998) and 15-21 $\mathrm{Tg}_{\text {year }}{ }^{-1}$ (Halmer et al., 2002). An important source of uncertainty in the inventory is the lack of $\mathrm{SO}_{2}$ emissions measurements for many volcanoes that remain unstudied, often located in remote parts of the world. For instance, there are rather few data representing emissions from volcanoes in Indonesia and Papua New Guinea. The same can be said of the Vanuatu arc, a group of 80 islands and islets in the Southwest Pacific. In fact, the first ground based estimates of $\mathrm{SO}_{2}$ emissions from Vanuatu volcanoes were only made in 2004 . Their contribution is therefore substantially underepresented in the databases for global volcanism, which in turn has implications for the global volcanic source strength, since estimates have not attempted to extrapolate to Vanuatu unmeasured volcanoes ( [Andres and Kasgnoc, 1998] and [Halmer et al., 2002] ). The few reported estimates of $\mathrm{SO}_{2}$ emissions prior to 2004 that are included, for instance, in the Andres and Kasgnoc (1998) database, were derived merely by comparing visual appearances of plumes with those for other measured volcanoes [12/1988 SEAN; 11/1990 BGVN].

Here, we report the first assessment of the volcanic $\mathrm{SO}_{2}$ budget for the Vanuatu arc, based on ultraviolet spectroscopic measurements of $\mathrm{SO}_{2}$ fluxes from the six principal active volcanoes of the archipelago in the period 2004-2009: Yasur, Lopevi, Ambrym, Ambae, Gaua and Vanua Lava, from south to north (Fig. 1). This includes both erupting volcanoes and persistently degassing ones. We provide new data for Yasur, Ambrym and Ambae and the first measurements for Vanua Lava, Gaua and Lopevi. 


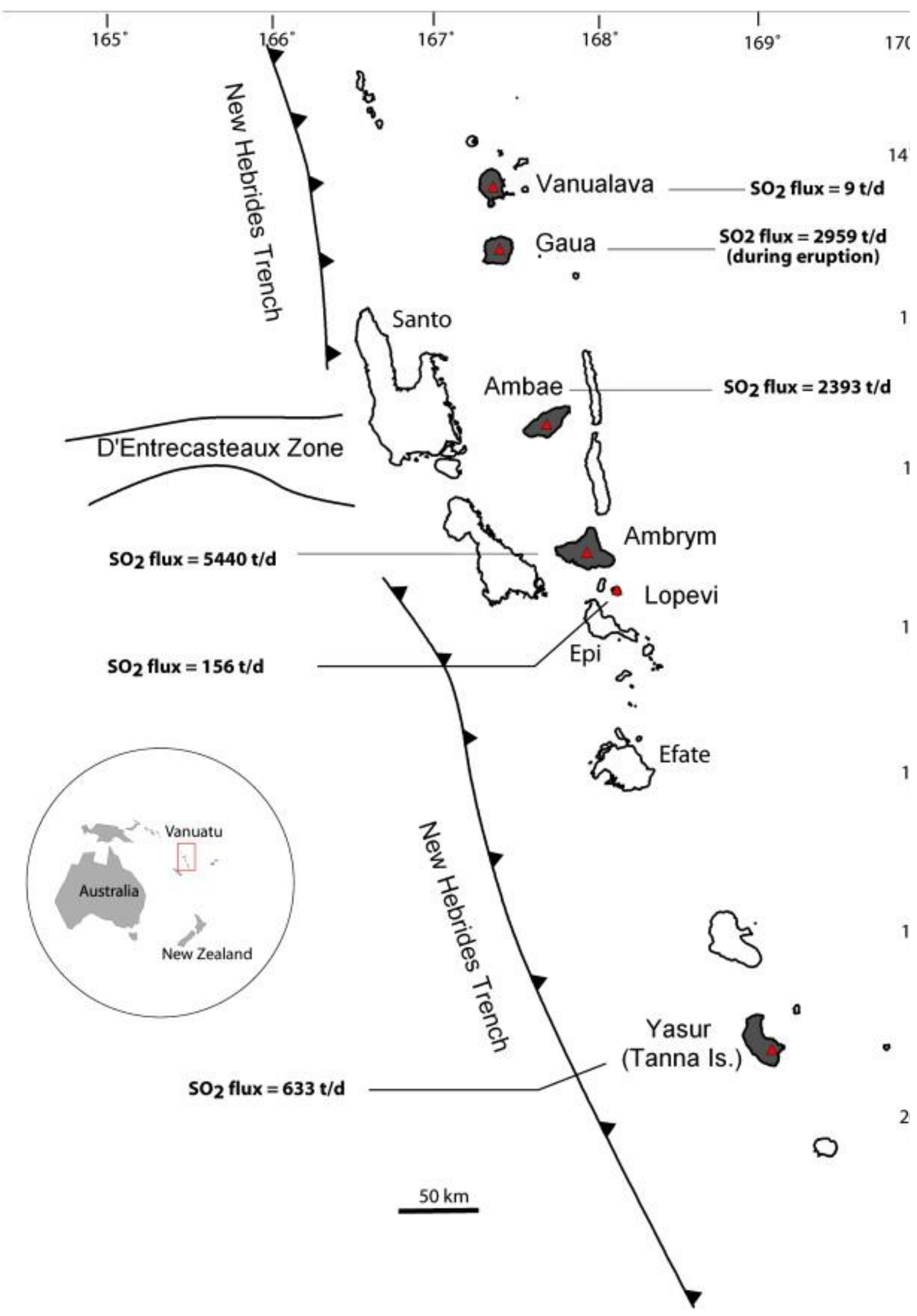

Fig. 1. :The Vanuatu island arc with the 6 studied active volcanoes (highlighted in grey). Note the position of Ambae and Ambrym, two large basaltic volcanoes in the central part of the arc, located at the collision zone between the arc and the d'Entrecasteaux ridge, an extension of the New Caledonia and Loyalty ridges [Laporte et al., 1998]. The mean $\mathrm{SO}_{2}$ emission rate from each volcano (Table 1) is indicated, except for Gaua where measurements were made during an ongoing explosive eruption. 


\section{Measurement locations}

The southern-most active volcano of Vanuatu is Yasur (Fig. 1). It is also the most accessible edifice of the archipelago. Yasur is the most active volcano of Vanuatu along with Ambrym. Its spectacular and ongoing strombolian activity attracts thousands of visitors each year. However unlike the other volcanoes of Vanuatu, Yasur is a small volcanic edifice reaching only $361 \mathrm{~m}$ (a.s.l.). Its crater hosts three vents from which magmatic gases are continuously released. The plume generally rises to 700-900 $\mathrm{m}$ (a.s.l.) and is then carried typically to the northwest by the trade winds. The spectroscopic measurements reported here were performed by road vehicle mostly on ash plain that lies $\sim 1 \mathrm{~km}$ northwest of crater (Fig. 2).

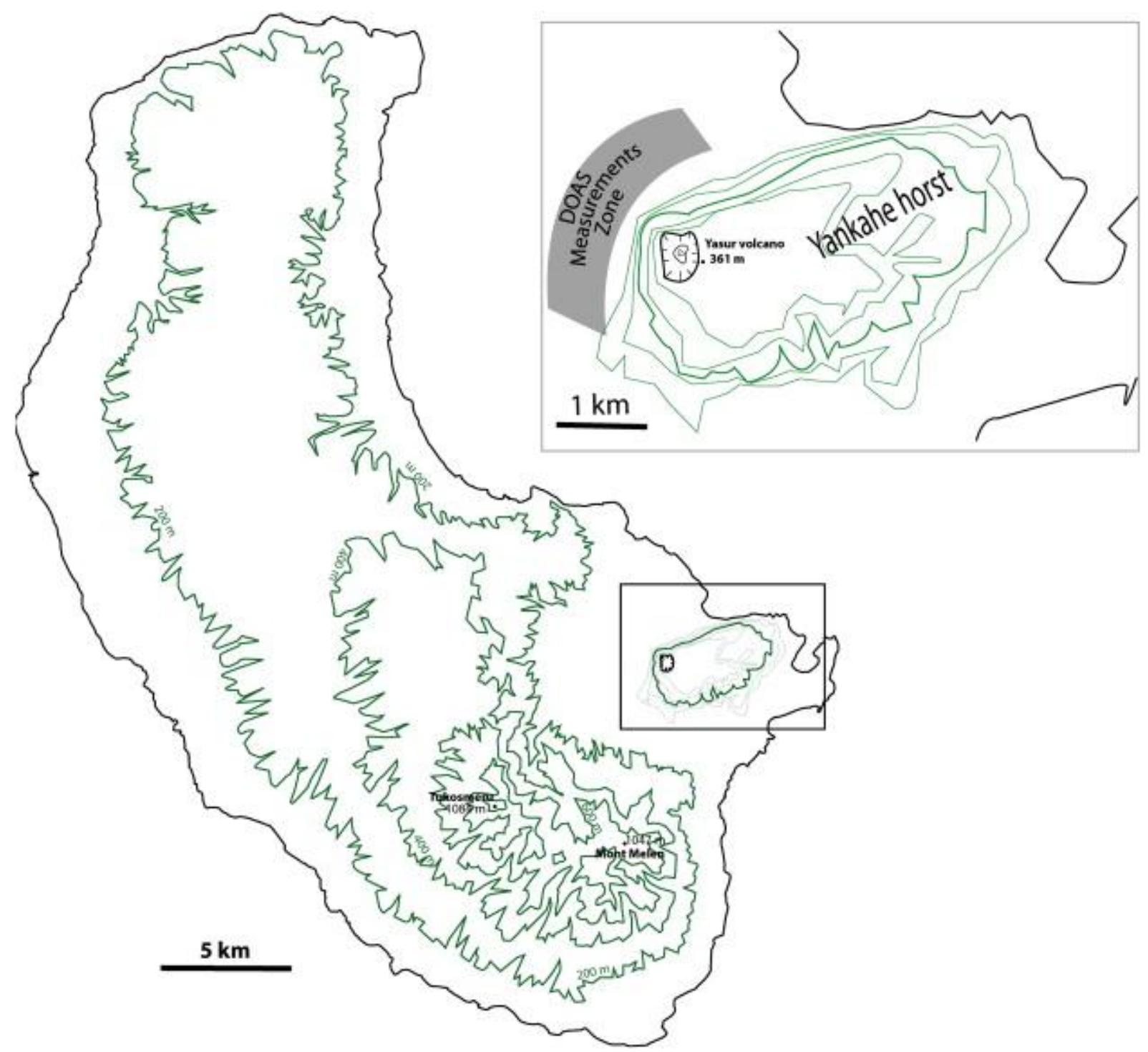

Fig. 2. : Yasur volcano is located on the eastern part of Tanna Island and occupies the western portion of the Yankahe resurgent block. This block went through a rapid uplift (156 mm/year) in the last 1000 years (Chen et al., 1995). DOAS measurements were performed in general northwest of the Yasur-highlighted in grey.

About $350 \mathrm{~km}$ NNW of Yasur is Lopevi (Fig. 1), another active volcano of Vanuatu with a nearperfect cone shape. It reaches $1413 \mathrm{~m}$ (a.s.1.). Lopevi was inhabited in the past but frequent eruptions ultimately forced the population out in 1967. There are two craters at the summit, aligned NW-SE 
(Fig. 3) but the present day vulcanian to sub-plinian eruptions occur only on the SE crater $(\sim 1300 \mathrm{~m}$ a.s.1.) (Fig. 3). This crater is also the principal source of degassing. Lava flows often occur following vigorous explosions. They originate along a NW-SE fracture zone that cuts through the volcanic edifice (paralleling the crater alignment) (Lardy and Bani, 2004). During explosions, plumes generally rise a few $\mathrm{km}$ above the crater, but for most of the time (between eruptions) the plume is weak and only rises a few tens of meters above the crater. Ultraviolet spectroscopic measurements were performed both from an aircraft flying at 700-1000 m (a.s.l.) and by boat, northwest of the crater (Fig. 3).

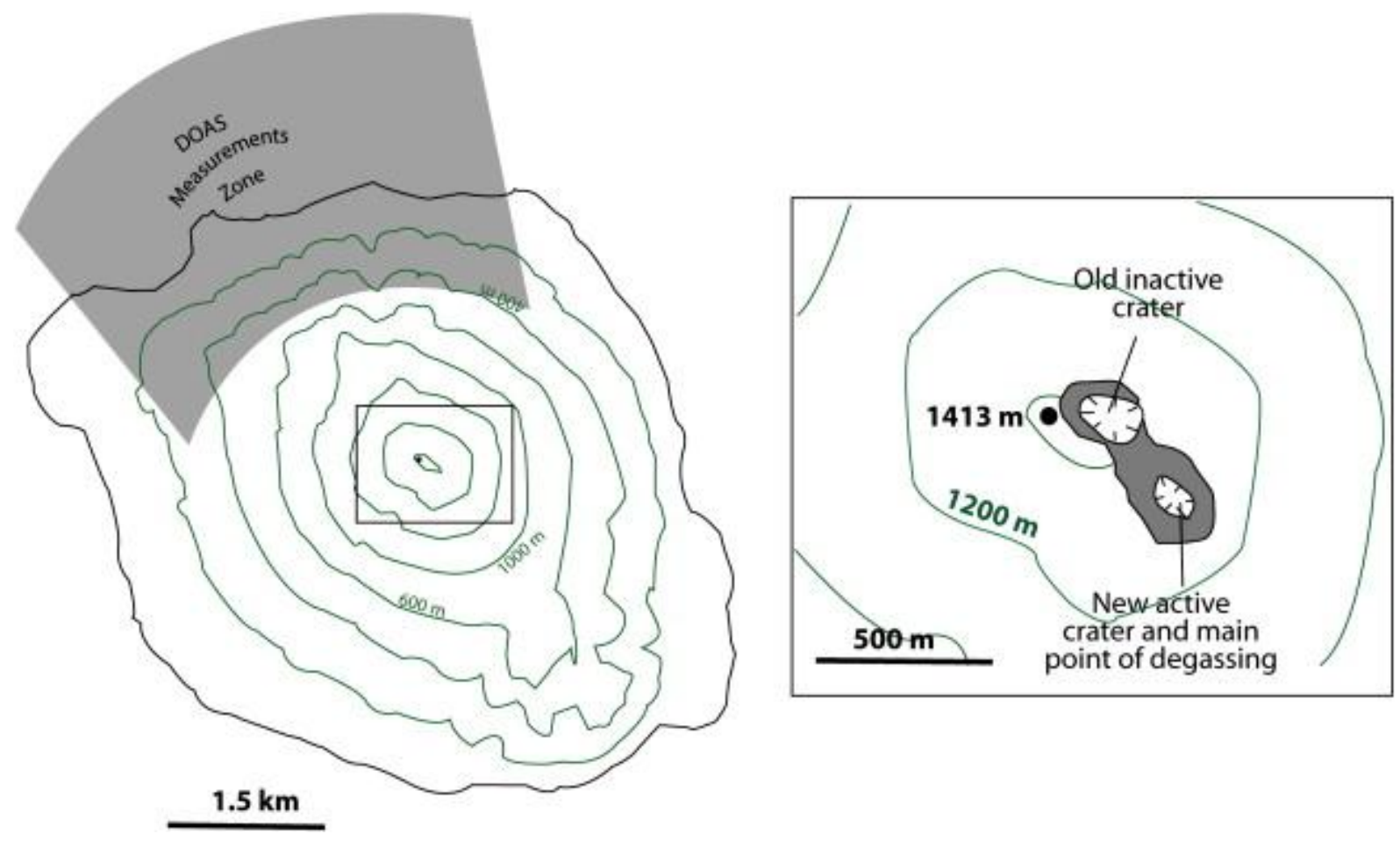

Fig. 3. : Lopevi volcano with its perfect cone shape. Its summit is occupied by 2 craters, an old inactive and a new active crater. Most of the present-day discharges occur on this new southeast crater. DOAS measurements zone is highlighted in grey.

Ambrym is situated $~ 30 \mathrm{~km} \mathrm{NW}$ of Lopevi (Fig. 1). Its summit is occupied by a 12-km-wide caldera that hosts the two main active craters, Benbow and Marum. Benbow has a well defined crater while Marum consists of three subcraters including Mbuelesu, Niri Mbuelesu and Maben Mbuelesu (Fig. 4). All these craters are active and sustain volatile emissions into the atmosphere. Recent activity has included the appearance of lave lakes and strombolian phases, as well as sporadic and ephemeral explosions at Mbuelesu. Lava lakes have been seen in all craters but they are most often present in Mbuelesu and Benbow's vent B (Fig. 4). The highest point of the volcano is $1270 \mathrm{~m}$ (a.s.1.), while the active craters reach around $1000 \mathrm{~m}$. Benbow and Marum generate two distinct plumes that typically rise 1-2 km above the craters before being bent over by the trade winds to the northwest. They ultimately merge downwind. In fair weather conditions (no rain) the merged plume typically drifts around 2000-3000 m (a.s.l.) and can be traced for several hundreds of $\mathrm{km}$ downwind. Spectroscopic measurements were generally performed from an aircraft flying at 700-1500 m (a.s.1.) to the northwest of the caldera. 


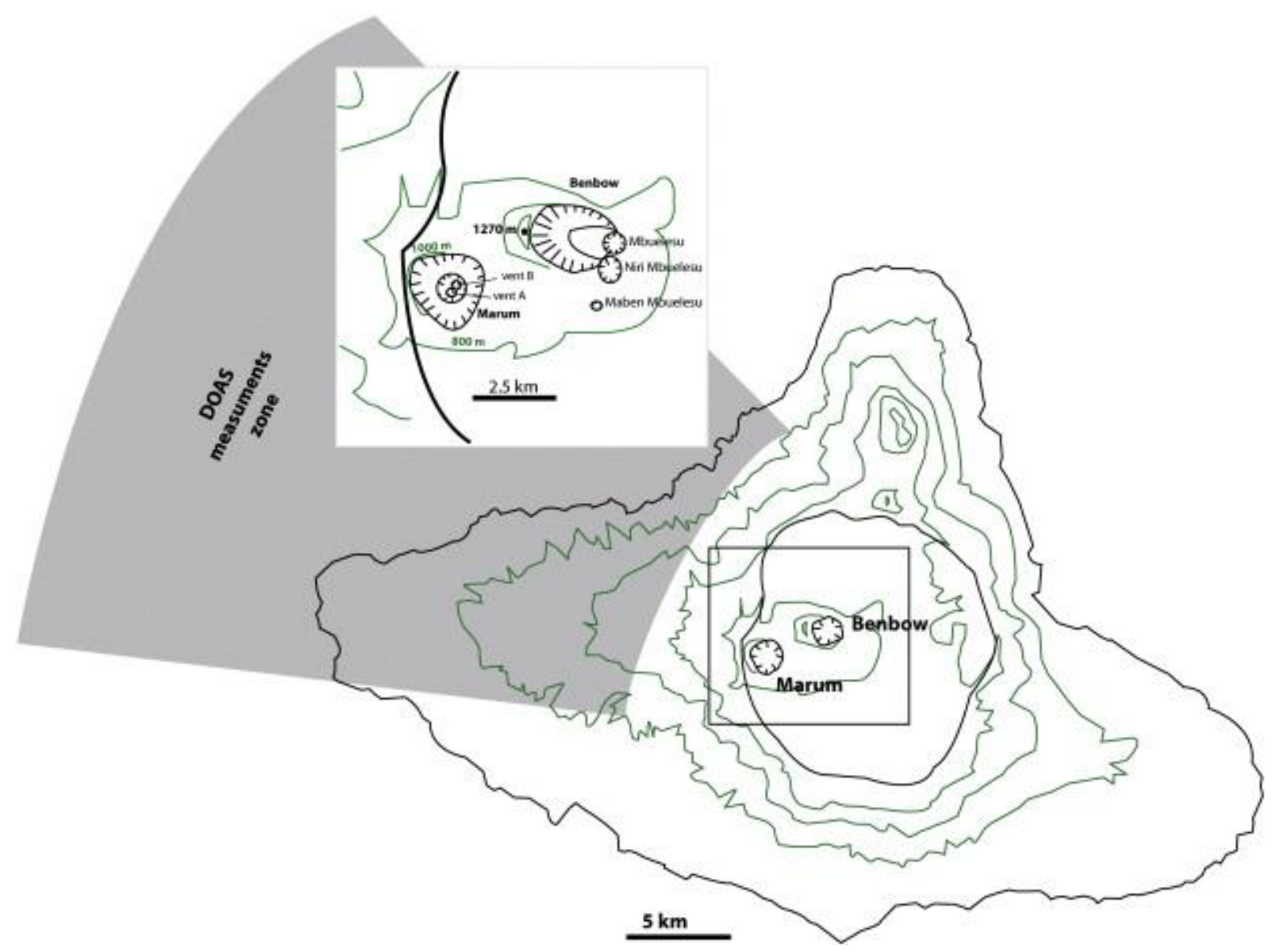

Fig. 4. : Ambrym is a triangle like shape island-volcano with $12 \mathrm{~km}$ wide summit caldera. The caldera hosts two main active craters Benbow and Marum. Marum is constituted by 3 subcraters known as Mbuelesu, Niri Mbuelesu and Maben Mbuelesu. Benbow has a well defined crater with two main active vents, A and B. DOAS measurements were generally performed northwest of the caldera-highlighted in grey.

The largest volcano in Vanuatu is Ambae, also know as Aoba. Situated $100 \mathrm{~km}$ north of Ambrym, it rises $3900 \mathrm{~m}$ above the sea floor. Its summit is occupied by two concentric calderas that host three crater lakes, including Manaro Ngoru, Manaro Lakua and Voui. The last of these has been the focus of recent volcanic activity (Fig. 5). It is also one of the largest acid lakes on Earth $\left(40 \times 10^{6} \mathrm{~m}^{3}\right)$. Amba's summit lakes collectively contain $50 \times 10^{6} \mathrm{~m}^{3}$ of water at an elevation of $\sim 1400 \mathrm{~m}$ above sea level. These perched lakes represent a potential hazard for thousands of people who live along the coast. The recent eruptive manifestations include a phreatic eruption in 1995 and surtseyan eruption in 2005-2006, and led to the evacuation of one third of the population living in the central part of the island. The formation of the new islet in Lake Voui during the 2005-2006 eruption isolated the active vent from the lake, allowing magmatic volatiles to discharge directly into the atmosphere (previously they were mostly condensed in the lake). The plume generally rises up to few hundred meters above the lake before being carried northwest by the trade winds. The downwind plume remains generally around 1500-2000 m (a.s.1.) and spectroscopic airborne measurements were generally performed at an altitude of $\sim 1000 \mathrm{~m}$ to the northwest of the caldera. 


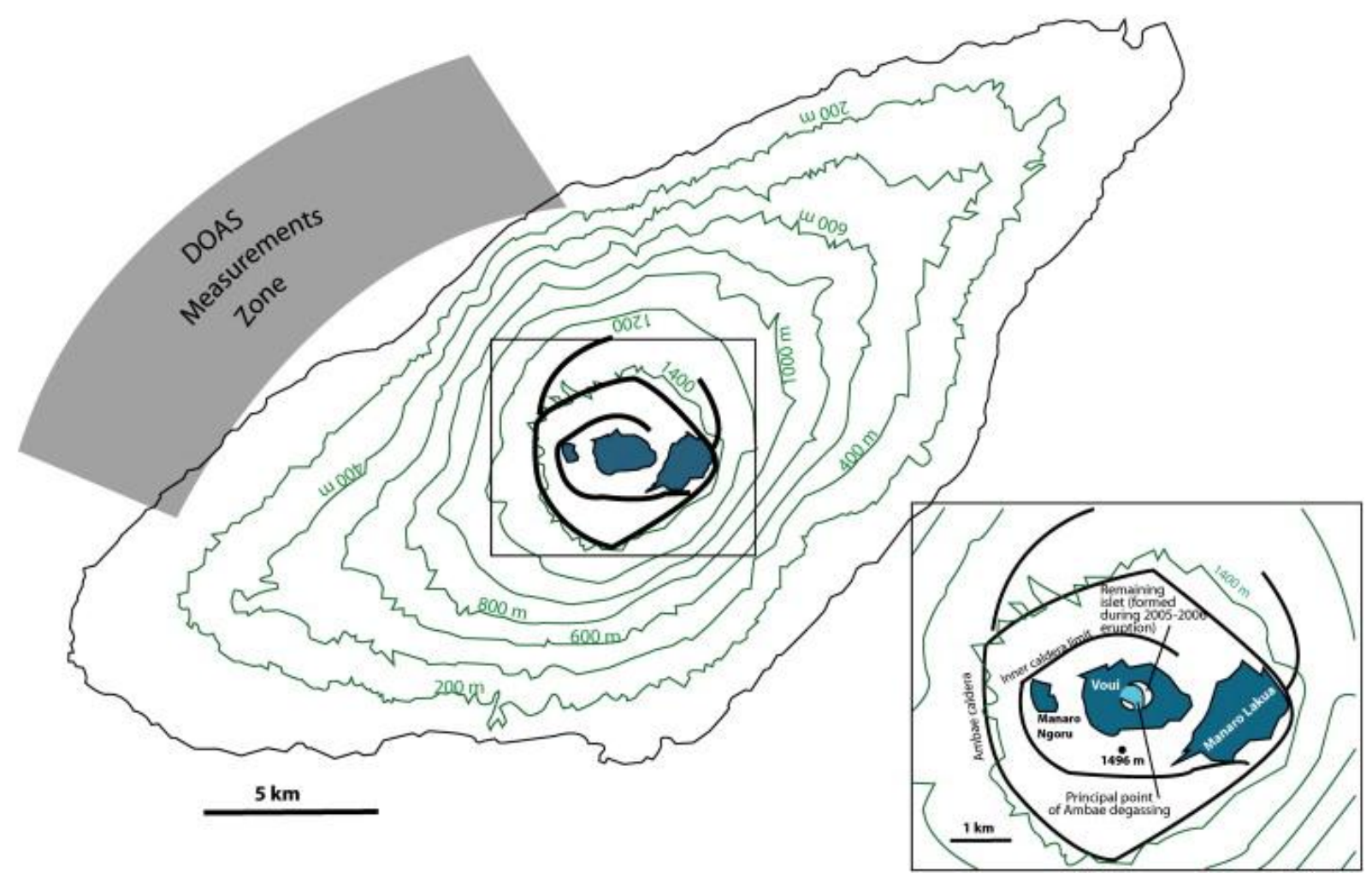

Fig. 5. : Ambae has a lozenge like shape. Its summit is occupied by concentric calderas that host 3 lakes: Manaro Lakua, Voui and Manaro Ngoru. Voui is the main point of volcanic degassing. The active vent is circumscribed by the eroded new islet. DOAS measurements generally performed northwest of the caldera, in grey.

Further north, at $125 \mathrm{~km}$ from Ambae is Gaua, whose activity in 2009-2010 prompted evacuation of more than 1500 inhabitants of the island from their villages. Gaua is a $40-\mathrm{km}-$ wide volcano rising $~ 3000 \mathrm{~m}$ from the sea bed. The summit caldera $\left(6 \times 8 \mathrm{~km}^{2}\right)$ is filled by a large crater lake (Lake Letas) in the middle of which rises Mt. Garet (797 m, a.s.1.), the active cone. This cone has two distinct craters (Fig. 6) and, since 1991, the activity has focused on the southeast crater, which was also the site of the 2009-2010 explosions (Fig. 6). This southeast crater (680 m, a.s.1.) is the main source of degassing. During the 2009-2010 eruption, the plume rose a few kilometers above the crater and spectroscopic measurements were performed from an aircraft flying at $1000 \mathrm{~m}$ (a.s.l.) to the northwest of the cone. 


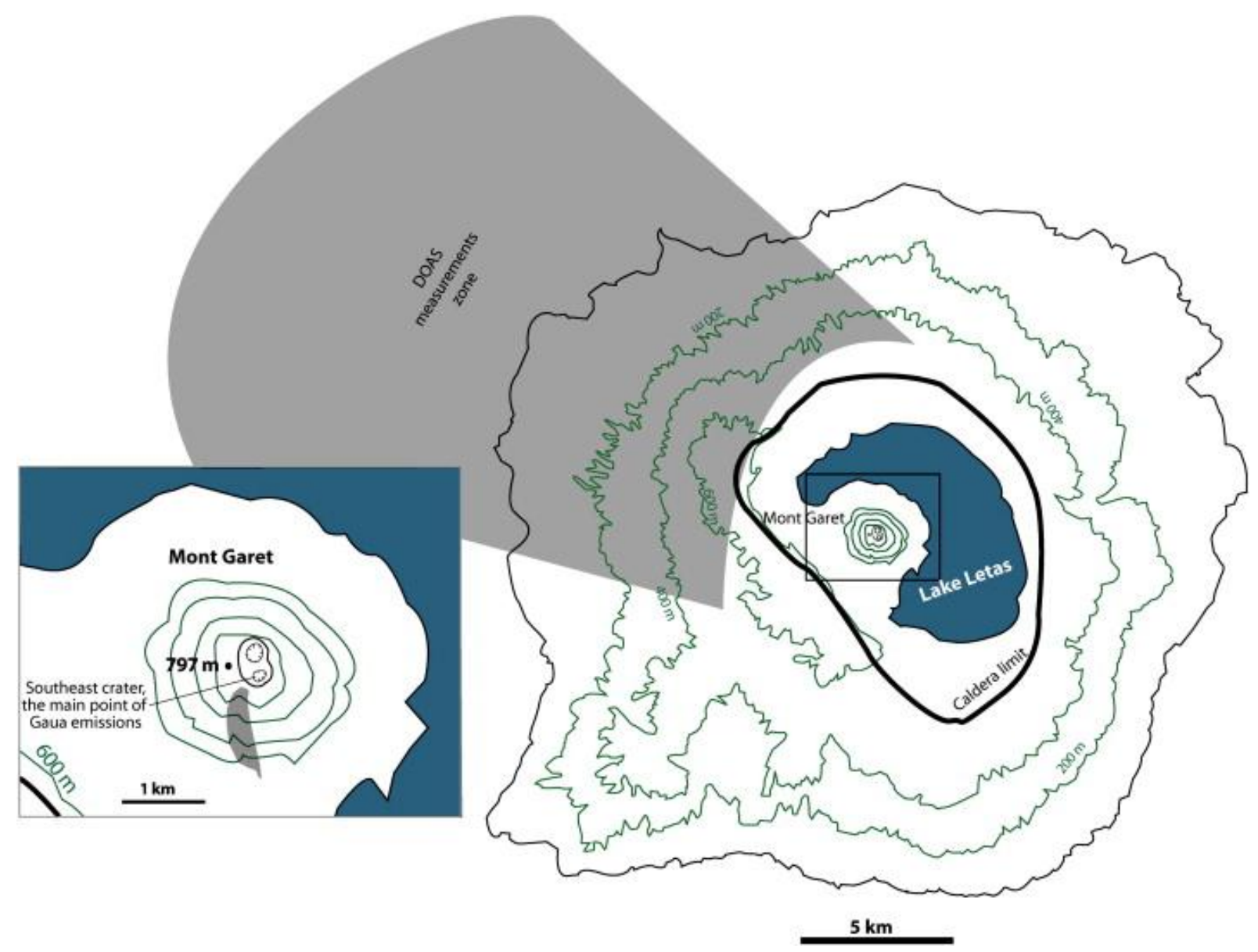

Fig. 6. : Gaua is a big volcano with a summit caldera and large crater lake, Letas. Present-day volcanic activity occurs on Mount Garet cone. The summit of this cone is occupied by two craters, but the main point of gas discharges is the southeast crater. DOAS measurements zone is highlighted in grey.

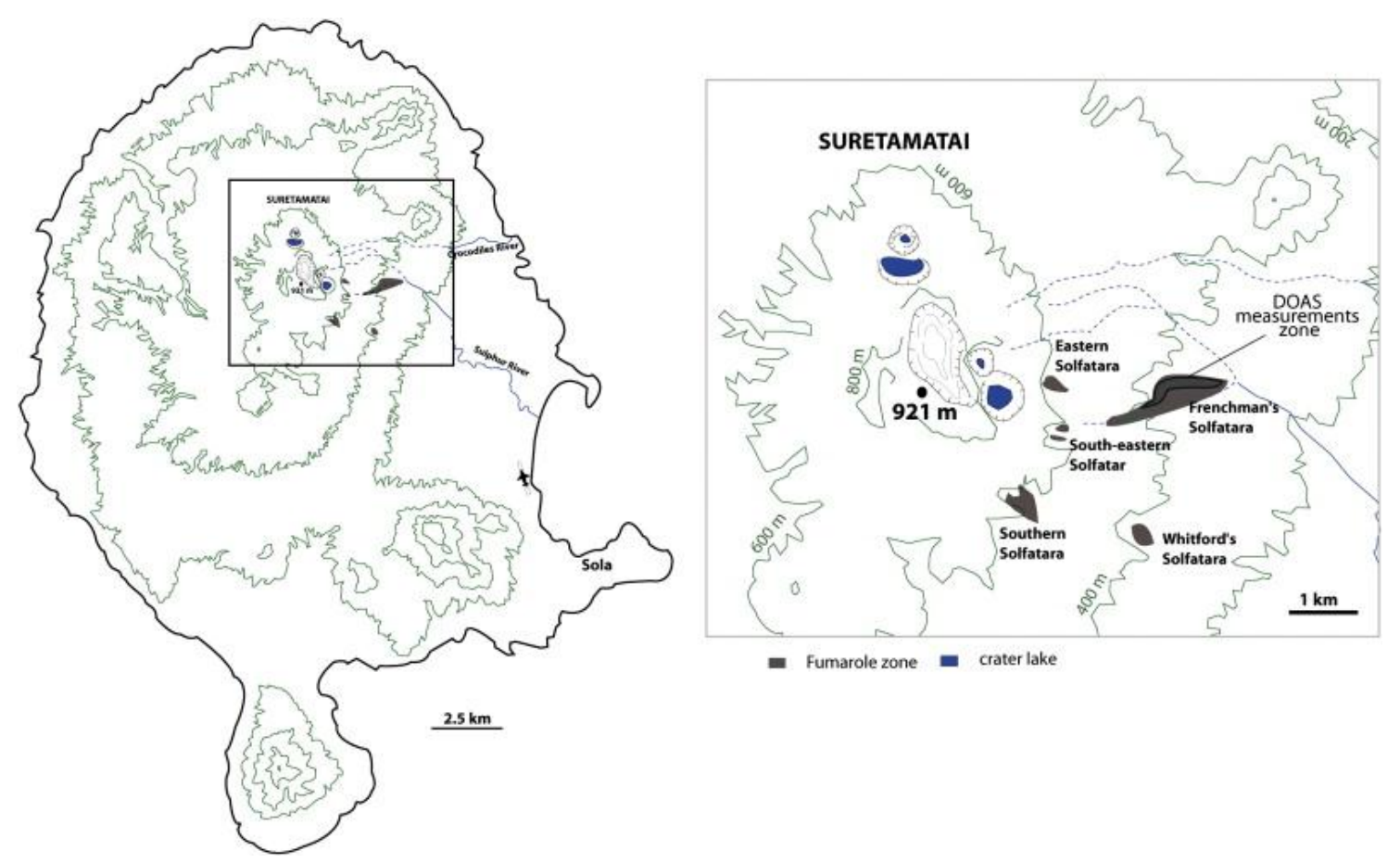

Fig. 7. : Vanua Lava is the least accessible volcano of Vanuatu. Its activity is mainly fumarolic with a least 5 solfatara zones. The Frenchman solfatara, where DOAS measurements were performed (highlighted in black) is the largest solfatara. 


\section{Ultraviolet spectrscopic measurements}

$\mathrm{SO}_{2}$ flux measurements were made using ultraviolet differential optical absorption spectroscopy (DOAS). At Ambrym, Ambae, Gaua and Lopevi volcanoes, spectroscopic measurements were performed onboard of an aircraft (Brittan-Norman Islander or U206G Cessna), following the traverse method (Bani et al., 2009a), flying just below the volcanic plumes in the cross-wind direction, and with the spectrometer's fiber-coupled telescope pointing to zenith. Flight altitudes ranged from $500 \mathrm{~m}$ to $2000 \mathrm{~m}$ above sea level. At Lopevi, traverses were also carried out from a boat. At Yasur, the most accessible volcano, $\mathrm{SO}_{2}$ fluxes were repeatedly measured from a 4WD vehicle, whereas on Vanua Lava, the least accessible volcano, fluxes were measured via on-foot traverses ( [McGonigle et al., 2002] and [Mori et al., 2006] ).

In total, $358 \mathrm{SO}_{2}$ flux measurements were made at the six active volcanoes of Vanuatu: 293 at Yasur, 33 at Ambrym, 19 at Ambae, seven at Gaua, four at Lopevi and two at Vanua Lava. A total of 55 days of fieldwork were necessary to assemble this dataset. We integrate here data that have been presented in our previous studies ( [Bani and Lardy, 2007] , [Bani et al., 2009a] and [Bani et al., 2009b] ) but more than two-thirds of the flux measurements reported here are new (Table 1). Measurement frequency has been strongly determined by access conditions, available funding and serendipity. Over the study period (2004-2009), we have used $86 \mathrm{~h}$ of flights for the airborne measurements (including time to reach and return from the volcanoes).

Table 1. $\mathrm{SO}_{2}$ emission rates from Vanuatu's volcanoes (Yasur, Ambrym, Ambae, Gaua, Lopevi and Vanualava) measured between 2004 and 2009. Passive and eruptive sporadic episodes of strong degassing are distinguished. The mean $\mathrm{SO}_{2}$ emission rate for each volcano is derived from the total number of DOAS traverses during the period of investigation, excluding the strongest sporadic volcanic phases.

\begin{tabular}{|c|c|c|c|c|c|c|c|c|c|c|c|}
\hline Volcano & $\begin{array}{l}\text { Volcanic } \\
\text { activity } \\
\text { during } \\
\text { traverses }\end{array}$ & $\begin{array}{l}\text { Date of } \\
\text { measurements }\end{array}$ & $\begin{array}{l}\text { Traverse } \\
\text { platform }\end{array}$ & $\begin{array}{l}\text { Traverse } \\
\text { number }\end{array}$ & $\begin{array}{l}\text { Start } \\
\text { time } \\
\text { (UT) } \\
\text { UT = } \\
\text { LT + } \\
11\end{array}$ & $\begin{array}{l}\text { Traverse } \\
\text { distance } \\
\text { from } \\
\text { source } \\
(\mathbf{k m})\end{array}$ & $\begin{array}{l}\text { Full } \\
\text { plume } \\
\text { width } \\
(\mathbf{k m})\end{array}$ & $\begin{array}{l}\text { Plume } \\
\text { altitude } \\
\text { (m) }\end{array}$ & $\begin{array}{l}\text { Average } \\
\text { column } \\
\text { amount } \\
\left(\mathrm{mg} / \mathrm{m}^{2}\right)\end{array}$ & $\begin{array}{l}\text { Mean } \\
\mathrm{SO}_{2} \\
\text { flux } \\
(\mathrm{kg} / \mathrm{s})\end{array}$ & $\begin{array}{l}\text { Source } \\
\text { references }\end{array}$ \\
\hline \multirow[t]{13}{*}{ Yasur } & $\begin{array}{l}\text { Strombolian } \\
\text { activity }\end{array}$ & $02 / 04 / 04$ & Vehicle & 3 & 00:35 & 0.9 & 0.8 & \multirow[t]{13}{*}{$700-900$} & 756 & $\begin{array}{l}4.3 \pm \\
1.4\end{array}$ & \multirow{13}{*}{$\frac{\frac{\text { Bani and }}{\text { Lardy }}}{\underline{(2007)}}$} \\
\hline & & 03/04/04 & & 4 & $23: 27$ & 0.9 & 3.0 & & 492 & $\begin{array}{l}2.6 \pm \\
0.8\end{array}$ & \\
\hline & & 04/04/04 & & 5 & $00: 28$ & 1.0 & 0.9 & & 844 & $\begin{array}{l}6.7 \pm \\
2.2\end{array}$ & \\
\hline & & $05 / 04 / 04$ & & 4 & 01:32 & 1.0 & 1.0 & & 384 & $\begin{array}{l}4.1 \pm \\
1.3\end{array}$ & \\
\hline & & 06/04/04 & & 4 & 00:30 & 1.1 & 0.9 & & 721 & $\begin{array}{l}5.2 \pm \\
1.7\end{array}$ & \\
\hline & & 07/04/04 & & 5 & $00: 55$ & 1.1 & 1.3 & & 788 & $\begin{array}{l}6.9 \pm \\
2.3\end{array}$ & \\
\hline & & $10 / 07 / 04$ & & 4 & $21: 40$ & 1.0 & 1.1 & & 778 & $\begin{array}{l}11.8 \pm \\
3.9\end{array}$ & \\
\hline & & $11 / 07 / 04$ & & 10 & $22: 43$ & 1.3 & 1.4 & & 2213 & $\begin{array}{l}13.9 \pm \\
4.6\end{array}$ & \\
\hline & & $12 / 07 / 04$ & & 14 & 00:42 & 1.0 & 0.8 & & 2301 & $\begin{array}{l}7.3 \pm \\
2.4\end{array}$ & \\
\hline & & $13 / 07 / 04$ & & 3 & 00:40 & 0.9 & 0.9 & & 3598 & $\begin{array}{l}9.3 \pm \\
3.1\end{array}$ & \\
\hline & & $14 / 07 / 04$ & & 2 & $23: 33$ & 1.0 & 0.6 & & 2842 & $\begin{array}{l}5.8 \pm \\
1.9\end{array}$ & \\
\hline & & $18 / 07 / 04$ & & 3 & $23: 49$ & 1.1 & 0.8 & & 1791 & $\begin{array}{l}4.8 \pm \\
1.6\end{array}$ & \\
\hline & & $19 / 09 / 04$ & & 2 & $23: 40$ & 1.0 & 0.9 & & 1780 & $5.1 \pm$ & \\
\hline
\end{tabular}




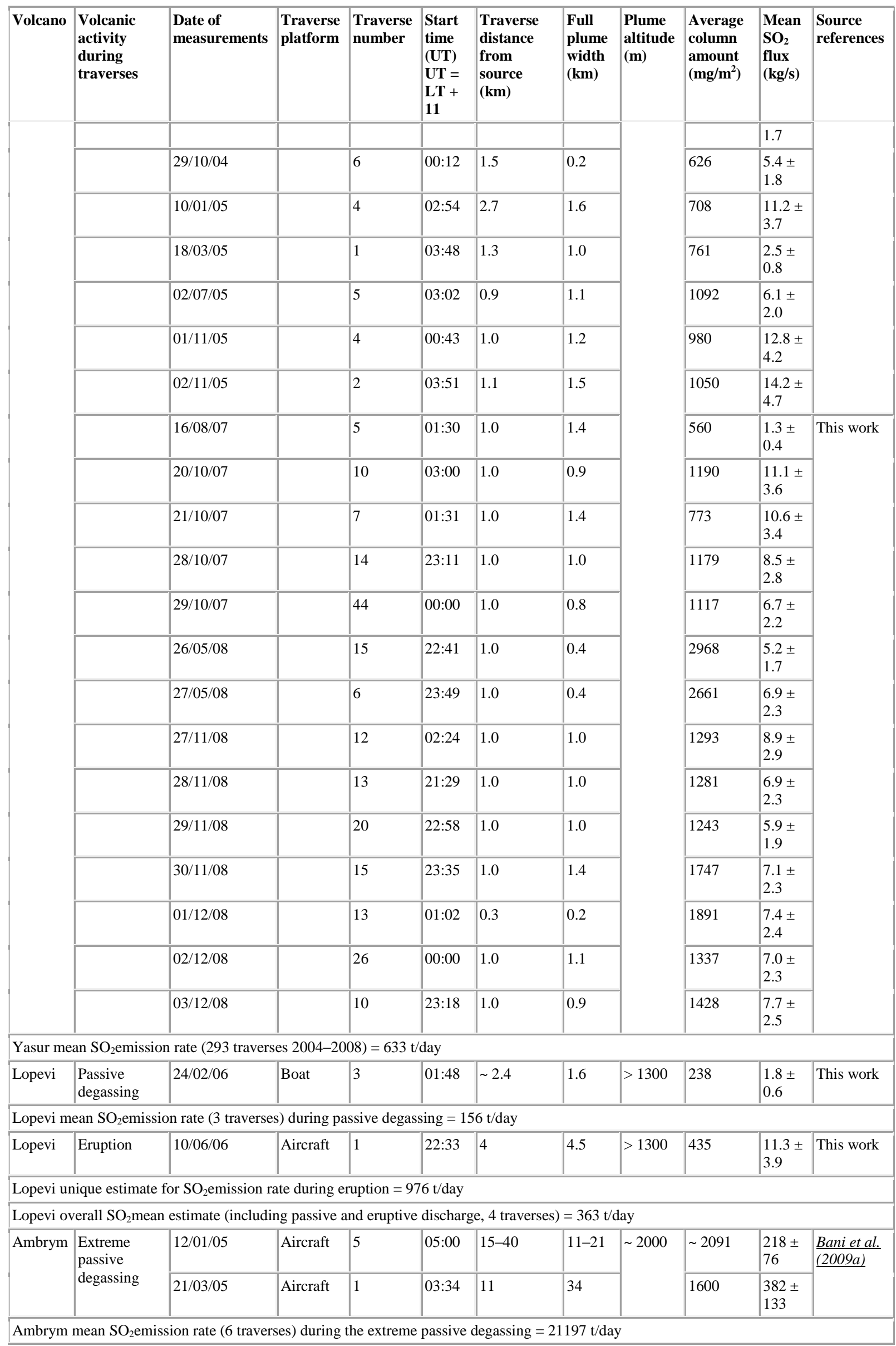




\begin{tabular}{|c|c|c|c|c|c|c|c|c|c|c|c|}
\hline Volcano & \begin{tabular}{|l} 
Volcanic \\
activity \\
during \\
traverses
\end{tabular} & $\begin{array}{l}\text { Date of } \\
\text { measurements }\end{array}$ & $\begin{array}{l}\text { Traverse } \\
\text { platform }\end{array}$ & $\begin{array}{l}\text { Traverse } \\
\text { number }\end{array}$ & \begin{tabular}{|l} 
Start \\
time \\
(UT) \\
UT = \\
LT + \\
11
\end{tabular} & $\begin{array}{l}\text { Traverse } \\
\text { distance } \\
\text { from } \\
\text { source } \\
(\mathbf{k m})\end{array}$ & $\begin{array}{l}\text { Full } \\
\text { plume } \\
\text { width } \\
(\mathbf{k m})\end{array}$ & \begin{tabular}{|l|}
$\begin{array}{l}\text { Plume } \\
\text { altitude } \\
\text { (m) }\end{array}$ \\
\end{tabular} & $\begin{array}{l}\text { Average } \\
\text { column } \\
\text { amount } \\
\left(\mathbf{m g} / \mathbf{m}^{2}\right)\end{array}$ & $\begin{array}{l}\text { Mean } \\
\mathrm{SO}_{2} \\
\text { flux } \\
(\mathbf{k g} / \mathbf{s})\end{array}$ & \begin{tabular}{|l} 
Source \\
references
\end{tabular} \\
\hline \multirow[t]{7}{*}{ Ambrym } & \multirow{7}{*}{$\begin{array}{l}\text { Passive } \\
\text { degassing }\end{array}$} & $11 / 07 / 05$ & Aircraft & 1 & 03:34 & 4 & 4 & \multirow{7}{*}{$\begin{array}{l}700- \\
2000\end{array}$} & 1210 & $25 \pm 8$ & \multirow{3}{*}{$\frac{\text { Bani et al. }}{(2009 a)}$} \\
\hline & & $10 / 11 / 05$ & Aircraft & 4 & $23: 43$ & $12-18$ & $20-31$ & & 193 & $32 \pm 9$ & \\
\hline & & $12 / 08 / 07$ & Aircraft & 3 & $03: 42$ & 13 & 5.6 & & 1197 & \begin{tabular}{|l|}
$46.7 \pm$ \\
16.3
\end{tabular} & \\
\hline & & $10 / 10 / 07$ & Aircraft & 4 & 22:19 & $4-12$ & $9-18$ & & 1428 & $\begin{array}{l}90.7 \pm \\
31.7\end{array}$ & \multirow[t]{4}{*}{ This work } \\
\hline & & $24 / 10 / 07$ & Aircraft & 4 & $03: 24$ & $14-16$ & $10-13$ & & 980 & $\begin{array}{l}84 \pm \\
29\end{array}$ & \\
\hline & & 08/10/08 & Aircraft & 6 & 03:30 & $16-24$ & $11-13$ & & 1309 & $\begin{array}{l}103 \pm \\
36\end{array}$ & \\
\hline & & $28 / 04 / 09$ & Aircraft & 5 & $00: 41$ & $11-12$ & $10-13$ & & 748 & \begin{tabular}{|l|}
$22.4 \pm$ \\
7.8
\end{tabular} & \\
\hline \multicolumn{12}{|c|}{ Ambrym mean $\mathrm{SO}_{2}$ emission rate (27 traverses) during passive degassing $=5440 \mathrm{t} / \mathrm{day}$} \\
\hline \multicolumn{12}{|c|}{ Ambrym overall $\mathrm{SO}_{2}$ mean estimate (including extreme and passive degassing, 33 traverses) $=8303 \mathrm{t} /$ day } \\
\hline \multirow[t]{2}{*}{ Ambae } & $\begin{array}{l}\text { Early } \\
\text { eruption } \\
\text { phase }\end{array}$ & $03 / 12 / 05$ & Aircraft & 3 & $21: 58$ & $3-6$ & $3-8$ & \multirow[t]{2}{*}{$\sim 2000$} & 1384 & $\begin{array}{l}15.8 \pm \\
5.5\end{array}$ & \multirow[t]{2}{*}{$\frac{\text { Bani et al. }}{\underline{(2009 b)}}$} \\
\hline & & $06 / 12 / 05$ & Aircraft & 2 & 05:03 & $8-9$ & $13-15$ & & 589 & $\begin{array}{l}24.2 \pm \\
8.5\end{array}$ & \\
\hline \multicolumn{12}{|c|}{ Ambae mean $\mathrm{SO}_{2}$ emission rate ( 5 traverses) during early eruption phase $=1655 \mathrm{t} / \mathrm{day}^{\mathrm{a}}$} \\
\hline \multirow[t]{5}{*}{ Ambae } & \multirow[t]{5}{*}{$\begin{array}{l}\text { Passive } \\
\text { degassing }\end{array}$} & $26 / 02 / 06$ & & 3 & $22: 47$ & $8-10$ & $18-20$ & \multirow[t]{5}{*}{$\begin{array}{l}1500- \\
2000\end{array}$} & 667 & $\begin{array}{l}27.0 \pm \\
9.5\end{array}$ & $\frac{\text { Bani et al. }}{(2009 b)}$ \\
\hline & & $10 / 06 / 06$ & Aircraft & 3 & $23: 39$ & $10-11$ & $10-14$ & & 1004 & \begin{tabular}{|l|}
$42.8 \pm$ \\
15.0
\end{tabular} & \multirow[t]{4}{*}{ This work } \\
\hline & & $12 / 08 / 07$ & Aircraft & 5 & $22: 31$ & $8-13$ & $8-11$ & & 304 & \begin{tabular}{|l|}
$20.8 \pm$ \\
7.3
\end{tabular} & \\
\hline & & 03/10/09 & Aircraft & 1 & $00: 25$ & 12 & 8 & & 271 & $\begin{array}{l}20.4 \pm \\
7.1\end{array}$ & \\
\hline & & $17 / 12 / 09$ & Aircraft & 2 & $02: 57$ & $12-14$ & 6-8 & & 304 & $\begin{array}{l}26.9 \pm \\
9.4\end{array}$ & \\
\hline \multicolumn{12}{|c|}{ Ambae mean $\mathrm{SO}_{2}$ emission rate (14 traverses) during passive degassing $=2393 \mathrm{t} /$ day } \\
\hline \multicolumn{12}{|c|}{ Ambae overall $\mathrm{SO}_{2}$ mean estimate (including eruptive and passive degassing, 19 traverses) $=2160 \mathrm{t} /$ day } \\
\hline \multirow[t]{3}{*}{ Gaua } & \multirow[t]{3}{*}{ Eruption } & 03/10/09 & Aircraft & 4 & 02:29 & $17-18$ & $5-13$ & \multirow[t]{3}{*}{$>2000$} & 1063 & $\begin{array}{l}35.0 \pm \\
12.3\end{array}$ & \multirow[t]{3}{*}{ This work } \\
\hline & & $14 / 10 / 09$ & Aircraft & 2 & $01: 49$ & $16-17$ & $6-8$ & & 675 & \begin{tabular}{|l|}
$31.9 \pm$ \\
11.1
\end{tabular} & \\
\hline & & $17 / 12 / 09$ & Aircraft & 1 & $04: 33$ & 27 & 16 & & 212 & $\begin{array}{l}35.7 \pm \\
12.5\end{array}$ & \\
\hline \multicolumn{12}{|c|}{ Gaua mean $\mathrm{SO}_{2}$ emission rate $(7$ traverses $)$ during eruption $=2959 \mathrm{t} / \mathrm{day}^{\mathrm{b}}$} \\
\hline $\begin{array}{l}\text { Vanua } \\
\text { Lava }\end{array}$ & Fumarole & 08/10/09 & Walking & 2 & $01: 32$ & $\begin{array}{l}\text { Traversing } \\
\text { across the } \\
\text { fumarole }\end{array}$ & $>0.2$ & $400-500$ & 2.3 & $\begin{array}{l}0.1 \pm \\
0.0\end{array}$ & This work \\
\hline \multicolumn{12}{|c|}{ Vanualava mean $\mathrm{SO}_{2}$ emission rate $(2$ traverses $)=9 \mathrm{t} /$ day $^{\mathrm{c}}$} \\
\hline \multicolumn{12}{|c|}{ Vanuatu $\mathrm{SO}_{2}$ emission budget estimated for passive degassing (Yasur, Lopevi, Ambrym, Ambae and Vanua Lava) $=8631 \mathrm{t} / \mathrm{day} \sim 3.1 \mathrm{Tg} / \mathrm{year}$} \\
\hline \multicolumn{12}{|c|}{ Vanuatu global emission budget estimate, including strong and passive degassing and eruptive emissions $=14700 \mathrm{t} / \mathrm{day} \sim 5.3 \mathrm{Tg} / \mathrm{year}$} \\
\hline
\end{tabular}

Ultraviolet (UV) spectra were collected with an Ocean Optics USB2000 UV spectrometer spanning the spectral range $280-400 \mathrm{~nm}$ with a spectral resolution of $0.5 \mathrm{~nm}$ FWHM. The spectrometer was coupled by a fiber-optic bundle to a telescope (field of view $8 \mathrm{mrad}$ ) pointed 
to zenith. For airborne traverses, the telescope was fixed outside the aircraft. Real time retrieval of $\mathrm{SO}_{2}$ column amounts, which is essential to track volcanic plumes from an aircraft, was made by means of DOASIS Jscripts ( [Kraus, 2006] and [Tsanev, 2008] ). Exposure time varied from 100 to $350 \mathrm{~ms}$, depending on light intensity, and 4-8 spectra were co-added to enhance the signal-to-noise ratio. The position of each UV spectrum was determined from a continuously recording GPS unit. $\mathrm{SO}_{2}$ column amounts were retrieved following standard DOAS calibration and analysis procedures ( [Kraus, 2006] and [Platt and Stutz, 2008] ). Retrieval scripts are available from the University of Cambridge (Tsanev, 2008). The reference spectra included in the non-linear fit were obtained by convolving high resolution $\mathrm{SO}_{2}$ (Bogumil et al., 2003) and $\mathrm{O}_{3}$ (Voigt et al., 2001) cross-sections with the instrument line shape. A Fraunhofer reference spectrum and Ring spectrum, calculated in DOASIS, were also included in the fit. The optimum fitting window of $310 \mathrm{~nm}$ to $336 \mathrm{~nm}$ was evaluated by obtaining a near random fit residual with minimum deviation. The same procedures were applied to ground-based measurements at Yasur, Lopevi and Vanua Lava. Plume speed is a key parameter for flux calculations. During airborne measurements it was obtained using the aircraft navigation system, from the difference in recorded ground speed when flying into and against the wind at the plume altitude (Bani et al., 2009a). For ground-based measurements, wind speed was measured with a hand held anemometer at plume altitude (e.g., the crater rim of Yasur). Although the anemometer accuracy is stated as $\pm 0.1 \mathrm{~m} \mathrm{~s}^{-1}$, there remains uncertainty in how representative the measured windspeeds are of the plume transport velocity. Errors in plume speed often represent a large source of uncertainty in $\mathrm{SO}_{2}$ flux calculations (Stoiber et al., 1983) but also significant are $\mathrm{SO}_{2}$ retrieval errors arising from in plume and near-field light scattering (Kern et al., 2010). Taking account of these uncertainties, following Mather et al. (2006), leads to an overall relative error of $35 \%$ to $48 \%$ on individual $\mathrm{SO}_{2}$ flux values (Table 1).

To gain longer temporal perspective of the Vanuatu arc emissions we have also made a preliminary investigation of observations from the spaceborne Ozone Monitoring Instrument (OMI) acquired over the period of 2004-2011. OMI is carried aboard NASA's polar-orbiting Aura satellite (Levelt et al., 2006). The operational algorithm used to retrieve $\mathrm{SO}_{2}$ column amounts from OMI measurements of ultraviolet (UV) radiance is reported in Yang et al. (2007).

\section{Results}

Table 1 and Fig. 8 reveal substantial differences in $\mathrm{SO}_{2}$ flux from the six studied volcanoes, which primarily reflect their levels of activity. The highest $\mathrm{SO}_{2}$ emission rate $\left(33 \mathrm{Gg} \mathrm{day}^{-1}\right)$ was recorded at Ambrym during a three-month pulse of strong lava lake degassing in 2005 (Bani et al., 2009a), while the smallest emission rate $\left(9 \mathrm{Mg}\right.$ day $\left.^{-1}\right)$ is from fumarolic activity on Vanua Lava. Ambrym is a predominantly basaltic volcano, with persistent lava lake activity and a prodigious plume emission that makes it by far the strongest source of $\mathrm{SO}_{2}$ in Vanuatu ( [Allard et al., 2009] and [Bani et al., 2009a] ). Its time-averaged output amounts to $5.4 \mathrm{Gg}_{\text {day }}{ }^{-1} \mathrm{SO}_{2}$ (Table 1), excluding the extreme degassing of 2005 (Bani et al., 2009a), which led to crop damage and food shortages, and which contributed to dental fluorosis as a result of water contamination by wet deposition of the plume (Allibone et al., 2010). Note, however, that the exceptional degassing rates in 2005 were not associated with explosive eruptions, highlighting the capacity of open-vent magmatic degassing to sustain extremely large $\mathrm{SO}_{2}$ owing to both magma convection in the conduit (e.g., Kazahaya et al., 1994) and differential gas transfer across low viscosity basaltic melt. 


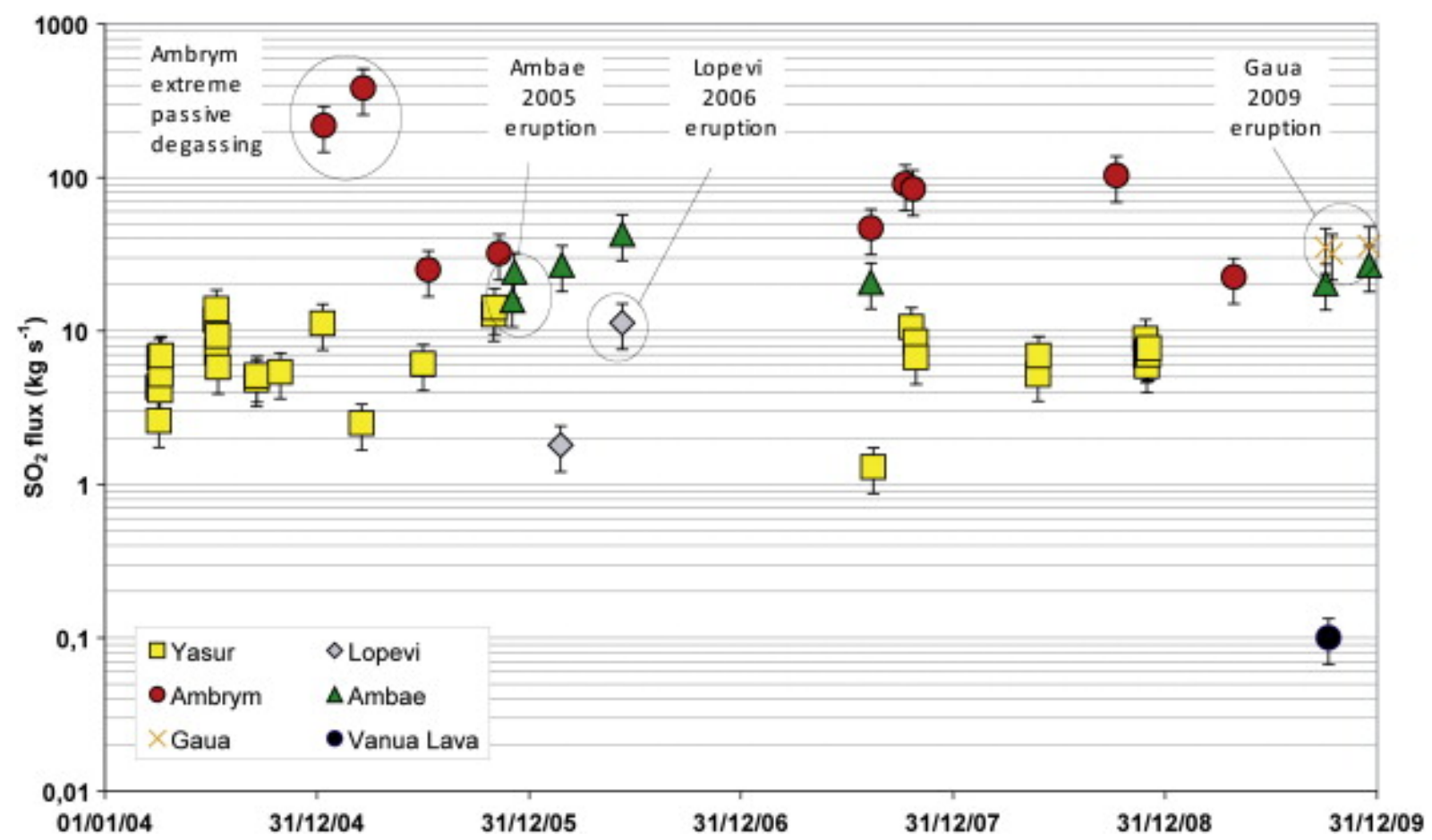

Fig. 8. : $\mathrm{SO}_{2}$ emission rates for the 6 active volcanoes measured between 2004 and 2009. The variable number of measurements reflects the comparative remoteness and difficulty of access to the different volcanoes. Yasur is the most accessible volcano, whereas Vanua Lava is difficult to reach. Eruptive episodes and periods of exceptionally high degassing are indicated. Note that the measurements performed on Ambae during an eruptive period cover just the initial phase when volcanic gases were released through the crater lake. During post eruptive measurement the active vent was isolated from the lake by a newly-formed islet, which enabled direct gas discharge into the atmosphere (see text).

Significant variability in $\mathrm{SO}_{2}$ flux, related to levels of volcanic activity, is further observed at Yasur (from < 200 to $1500 \mathrm{Mg}$ day $^{-1}$ ( [Bani and Lardy, 2007] and [Métrich et al., 2011] )), Lopevi (from 156 to $980 \mathrm{Mg}$ day $^{-1}$ ), and Ambae (between 1 and $4 \mathrm{Gg}$ day $^{-1}$ ). Note that the $\mathrm{SO}_{2}$ flux results obtained during an eruption phase of Ambae in early 2005 are significantly lower than the post-eruption emission rates due to effective gas scrubbing by the $40 \times 10^{6} \mathrm{~m}^{3}$ hot and acid (pH 1-3) crater lake ( [Bani et al., 2009b] and [Bani et al., 2009c] ). The $\mathrm{SO}_{2}$ flux progressively increased from 1 to $4 \mathrm{Gg}_{\text {day }}{ }^{-1}$ along with intrusion followed by extrusion of magma that formed a new islet (a tephra cone with a subaerial vent; ( [Bani et al., 2009b] and [Nemeth et al., 2006] ). Four years after the eruption, $\mathrm{SO}_{2}$ was still being released at a high rate $\left(\sim 2 \mathrm{Gg} \mathrm{day}^{-1}\right)$ through the newly formed islet, indicating a sustained input of magmatic volatiles. Another significant eruption that occurred in our study period is that of Gaua in 2009 (10/2009 BGVN 34:10; 12/2009 BGVN 34:12). This eruption was underway by late September 2009, after 50 years of fumarolic activity, and forced the evacuation of half of the island's 3000 inhabitants. The $\mathrm{SO}_{2}$ output rose from a very low level before the eruption $\left(\mathrm{SO}_{2}\right.$ was undetected by DOAS in 2007) up to $3 \mathrm{Gg}_{\text {day }}{ }^{-1}$ in October-December 2009 (Table 1) when an eruption column rose a few $\mathrm{km}$ above the volcano. A smaller eruption occurred in May-June 2006 on Lopevi (02/2007 BGVN 32:02). Measurements performed during this period indicate an $\mathrm{SO}_{2}$ output of $1 \mathrm{Gg}_{\text {day }}{ }^{-1}$ contrasting with $0.2 \mathrm{Gg}_{\text {day }}{ }^{-1}$ before and after the eruptive episode.

Daily OMI $\mathrm{SO}_{2}$ measurements (at 13:45 h local time) provide unique constraints on the variability of Vanuatu-arc volcanic degassing, particularly in the data gaps between DOAS data acquisitions (Fig. 8). However, it is important to note that space-based sensors such as 
OMI provide a measurement of integrated $\mathrm{SO}_{2}$ mass in a scene rather than emission rates from a volcanic source. Hence, whilst we do not typically expect $\mathrm{OMI} \mathrm{SO}_{2}$ burdens to be commensurate with DOAS-derived $\mathrm{SO}_{2}$ emission rates, both techniques should track relative changes in degassing rates. Meteorological cloud is the main impediment to satellite detection of lower tropospheric $\mathrm{SO}_{2}$ plumes, and synoptic or orographic clouds can cover the tropical Vanuatu volcanoes at any time of year. However, we observe no strong seasonal dependence in the $\mathrm{OMI} \mathrm{SO}_{2}$ data (Fig. 9), suggesting that the volcanic source strength is the principal modulating factor.

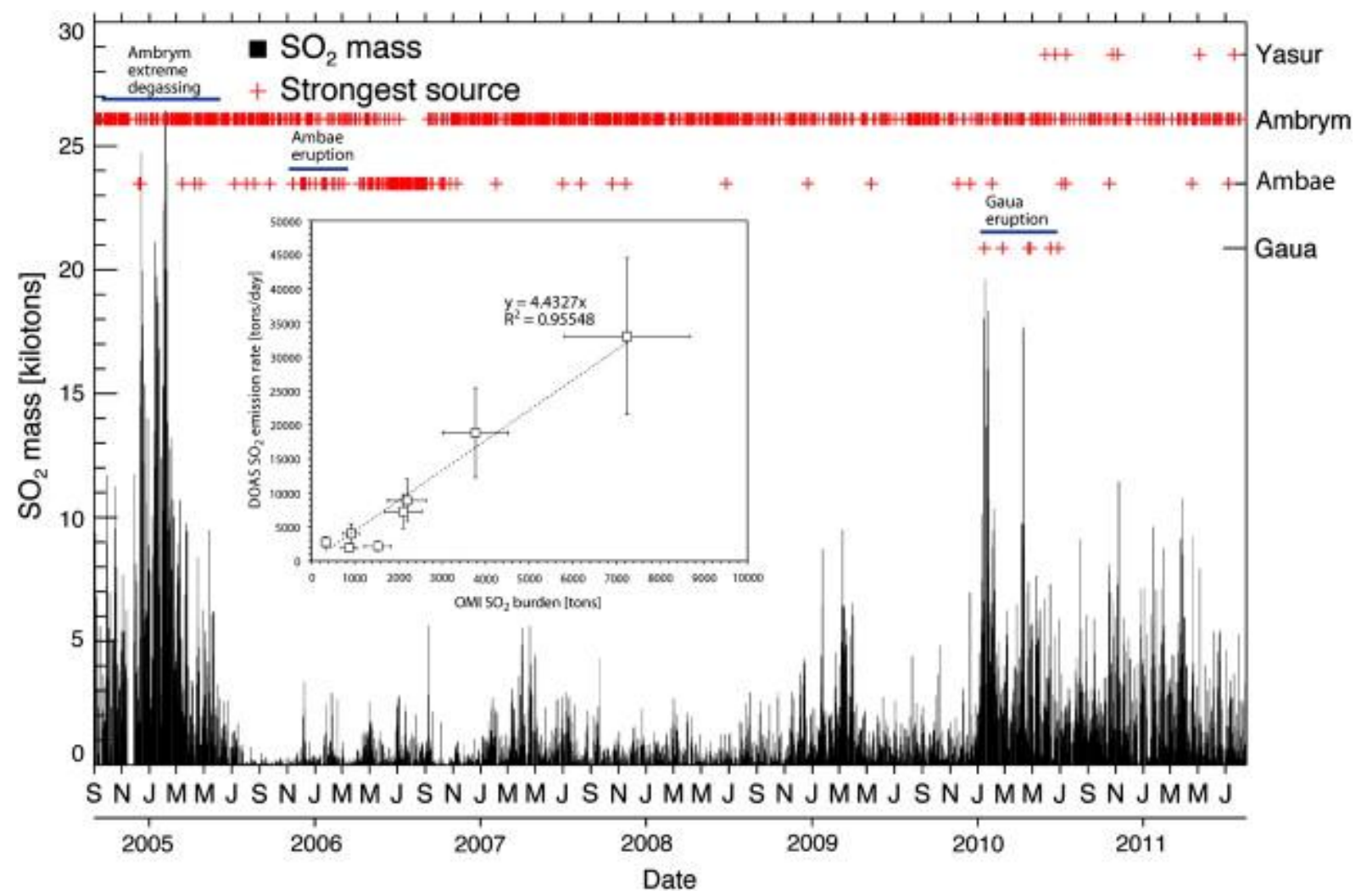

Fig. 9. : Daily $\mathrm{SO}_{2}$ mass (kilotons) measured by OMI over the Vanuatu archipelago (latitude $10-22^{\circ} \mathrm{S}$, longitude $156-178^{\circ} \mathrm{E}$ ) from September 2004 to August 2011. The geographic domain covers emissions from all the active Vanuatu volcanoes discussed here. The operational OMI Linear Fit $\mathrm{SO}_{2}$ retrieval used here assumes a fixed $\mathrm{SO}_{2}$ plume altitude of $\sim 3 \mathrm{~km}$ asl (Yang et al., 2007). According to plume altitudes given in Table 1 this could result in an underestimation of $\mathrm{SO}_{2}$ amounts of up to $\sim 30 \%$. Strongest source indicates the volcanoes (Gaua, Aoba, Ambrym or Yasur) located closest to the center of the OMI pixel containing the maximum $\mathrm{SO}_{2}$ column amount retrieved on each day (Carn et al., 2008). Volcanoes located $>50 \mathrm{~km}$ (for Gaua, Aoba and Ambrym) or $>100 \mathrm{~km}$ (for Yasur) from the $\mathrm{SO}_{2}$ maximum were excluded. Lopevi was also excluded as a potential source due to its proximity to Ambrym. Note that on many days $\mathrm{SO}_{2}$ plumes from multiple volcanoes are present and the reported $\mathrm{SO}_{2}$ mass then represents aggregated emissions from all sources. Inset shows a comparison between $\mathrm{OMI} \mathrm{SO}_{2}$ burdens and DOAS SO 2 emission rates for Ambrym (Table 1), measured on same days. The two datasets are well correlated, and based on the linear regression shown we obtain a scaling factor to estimate $\mathrm{SO}_{2}$ emission rates from OMI SO 2 burdens.

A time-series of $\mathrm{OMI} \mathrm{SO}_{2}$ data for Vanuatu shown in Fig. 9 comprises more than 2400 daily observations. Since measurements began in September 2004, OMI has detected $\mathrm{SO}_{2}$ emissions from all the active Vanuatu volcanoes with the exception of Vanua Lava. Fig. 9 suggests significant variability of $\mathrm{SO}_{2}$ emissions from the arc on monthly and annual timescales. The OMI data confirm the exceptional level of degassing from Ambrym in late 2004 and early 2005 that was also captured by DOAS measurements (Fig. 8); comparably high $\mathrm{SO}_{2}$ burdens were also measured by OMI in early 2010 but the latter can be attributed to simultaneous high levels of activity at Gaua, Ambrym and (to a lesser extent) Yasur rather than Ambrym alone. Fig. 9 also confirms Ambrym's predominance as the major and most persistent $\mathrm{SO}_{2}$ source in the arc, with the notable exception of a period in 2006 when degassing from Aoba prevailed. Furthermore, the relative frequency of source attribution for 
the four volcanoes specified in Fig. 9 is consistent with their respective average passive degassing rates reported in Table 1.

\section{Discussion}

Sporadic and episodic volcanic events, such as the extreme gas emissions from Ambrym in 2005 and the explosive eruptions (Ambae: 2005; Gaua: 2009; Lopevi: 2006), can be relatively ephemeral and may not be representative of time-averaged volcanic emissions. We therefore exclude these sporadic events, to estimate mean $\mathrm{SO}_{2}$ outputs from Yasur, Lopevi, Ambrym, Ambae and Vanua Lava of 633, 156, 5440, 2393, and $9 \mathrm{Mg}$ day $^{-1}$ respectively. Assuming that these figures are representative for time-averaged subaerial degassing of the volcanoes, then the total $\mathrm{SO}_{2}$ emission rate for the whole arc during the period of 2004-2009 is $3.1( \pm$ $0.8)$ Tg year $^{-1}$. This first Vanuatu island arc assessment is surely an approximation given the limited data coverage, and likely to be an underestimate given exclusion of the results for the most vigorous periods of activity on particular volcanoes. If we put the sporadic emissions back into the calculation, the inventory rises to $5.3( \pm 1.1) \mathrm{Tg}$ year $^{-1}$. Space-borne OMI coverage indicates a total cumulative $\mathrm{SO}_{2}$ mass of $\sim 4.3 \mathrm{Tg}$ released by Vanuatu volcanoes in 2004-2011 (Fig. 9). However, if we compare DOAS and OMI measurements for Ambrym on same days, we find that $\mathrm{OMI} \mathrm{SO} \mathrm{S}_{2}$ burdens amount to only $\sim 23 \%$ of the corresponding daily $\mathrm{SO}_{2}$ emission rates measured with DOAS (Fig. 9). Such a discrepancy is most likely due to the combined effects of the constant $\mathrm{SO}_{2}$ plume altitude assumption in the $\mathrm{OMI} \mathrm{SO}_{2}$ retrieval, meteorological clouds, rapid $\mathrm{SO}_{2}$ loss rates (via chemical reactions and wet/dry deposition) in the tropical atmosphere of Vanuatu and OMI dection limit. Adopting this scaling factor for the entire OMI dataset, and considering that Ambrym is by far the dominant $\mathrm{SO}_{2}$ source, yields a cumulative $\mathrm{SO}_{2}$ emission of $\sim 19 \mathrm{Tg}$ in 2004-2011. This results in an average annual emission of $\sim 2.7 \mathrm{Tg}$ year $^{-1}$ over the 7 years, coherent with our estimate from DOAS sensing.

These first results thus suggest that the Vanuatu arc is one of the strongest sites of contemporary volcanic degassing on Earth. In comparison, estimates for regional $\mathrm{SO}_{2}$ emission range from 1.6 $\mathrm{Tg}_{\text {year }}{ }^{-1}$ for Central America (Mather et al., 2006), $1.2 \mathrm{Tg} \mathrm{year}^{-1}$ for Papua-New Guinea (McGonigle et al., 2004), and 2.1-3.5 $\mathrm{Tg}_{\text {year }}{ }^{-1}$ for Indonesia ( [Nho et al., 1996] and [Halmer et al., 2002] , though this estimate is based more on extrapolation and inference rather than actual measured $\mathrm{SO}_{2}$ emissions). Our estimate for Vanuatu's volcanoes, which have hitherto been almost absent from global inventories, is equivalent to $20 \%$ of published estimates of the global volcanic $\mathrm{SO}_{2}$ output ( [Andres and Kasgnoc, 1998] and [Halmer et al., 2002] ).

Our new dataset reported here confirms the very substantial and sustained degassing from Ambrym, whose mean $\mathrm{SO}_{2}$ emission rate of $5.4( \pm 1.6) \mathrm{Gg}_{\text {day }}{ }^{-1}$ represents $\sim 63 \%$ of the arc's $\mathrm{SO}_{2}$ output. Ambrym ranks alongside Etna as one of the largest persistent sources of volcanic degassing worldwide ([Allard et al., 1991] and [Andres and Kasgnoc, 1998] ). Our new dataset also highlights intense $\mathrm{SO}_{2}$ emission from Ambae with $2.4( \pm 0.5) \mathrm{Gg}_{\text {day }}{ }^{-1}$, representing $\sim 28 \%$ of the arc budget eventhough the sulphur budget at this volcano is probably underestimated due to $\mathrm{SO}_{2}$ scrubbing by a vigorous hydrothermal system and associated large $\left(40 \times 10^{6} \mathrm{~m}^{3}\right)$ acid $(\mathrm{pH}<3)$ crater lake (Bani et al., 2009b). Ambrym and Ambae basaltic volcanoes, located in the central part of the arc, thus emit more than $90 \%$ of the Vanuatu $\mathrm{SO}_{2}$ budget. Further work is needed to understand the causes of such elevated degassing. It is worthy of note that the central arc segment is subjected to both a westward inflow of enriched, possibly sulphur-rich Indian-type MORB mantle ( [Monzier et al., 1997], [Peate et al., 1997] and [Turner et al., 1999] ) and to the collision with the d'Entrecasteaux 
ridge since 2-3 Ma ( [Collot et al., 1985] , [Collot et al., 1992] , [Burne et al., 1988] , [Greene and Collot, 1994] , [Taylor et al., 1994] and [Laporte et al., 1998] ) that has led to back-arc shortening ( [Collot et al., 1985] and [Louat and Pelletier, 1989] ) and to the development of tranverse fracture zones which may facilitate magma ascent beneath Ambae and Ambrym ( [Pontoise et al., 1994] , [Baker and Condliffe, 1996] and [Monzier et al., 1997] ).

\section{Conclusions}

We provide the first volcanic $\mathrm{SO}_{2}$ emission budget at the arc scale for the Vanuatu archipelago, based on repeated DOAS measurements in 2004-2009 and space-borne OMI survey in 2004-2011. This reveals the arc to emit around $3 \mathrm{Tg}_{\text {year }}{ }^{-1}$ of $\mathrm{SO}_{2}$ into the atmosphere on average, without considering sporadic eruptions or/and extreme passive degassing events. Such a budget represents about one-fifth of currently estimated global volcanic $\mathrm{SO}_{2}$ output and, therefore, highlights that the Vanuatu archipelago will have to be taken into account in updating global volcanic inventories in future.

Our results confirm the prodigious degassing of Ambrym volcano, with an average $\mathrm{SO}_{2}$ output of $5 \mathrm{Gg}_{\text {day }}{ }^{-1}$, representing nearly two-thirds of the Vanuatu $\mathrm{SO}_{2}$ budget. This places Ambrym in the top rank of persistent volcanic volatile sources worldwide, alongside Mount Etna in Sicily. Ambae volcano also emerges as a prominent $\mathrm{SO}_{2}$ source, with an output of $\sim 2$ $\mathrm{Gg}_{\text {day }}{ }^{-1}$ representing $28 \%$ at least of the arc budget. Further work will be needed to elucidate whether such elevated degassing at Ambrym and Ambae results from the inflow of S-rich Indian-type mantle beneath the central segment of Vanuatu arc or/and high magma production rates facilitated by the complex local tectonic structure.

\section{Acknowledgments}

We gratefully acknowledge supports from ADECAL (under the regional cooperation program with Vanuatu in 2006-2008), from the Agence National de la Recherche (France) through the 'Arc-Vanuatu' and'Volgaspec'projects (2007-2010), and from the Fond Pacifique. CO and VT thank the UK Natural Environment Research Council for support via the National Centre for Earth Observation "Dynamic Earth and Geohazards" program. PA's contribution is referred to as IPGP contribution 3230. Anonymous reviews are acknowledged.

\section{References}

Allard et al., 1991 P. Allard, J. Carbonnelle, D. Dajlevic, J. Le Bronec, P. Morel, J.M. Maurenas, M.C. Robe, R. Faivre-Pierret, J.C. Sabroux and P. Zettwoog, Eruptive and diffuse emissions of carbon dioxide from Etna volcano. Nature, 351 (1991), pp. 38-391.

Allard et al., 1994 P. Allard, J. Carbonnelle, N. Métrich, H. Loyer and P. Zettwoog, Sulphur output and magma degassing budget of Stromboli volcano. Nature, 368 (1994), pp. 326330.

Allard et al., 2009 P. Allard, A. Aiuppa, P. Bani, N. Métrich, A. Bertagnini, P.-J. Gauthier, F. Parello, G. Sawyer, H. Shinohara, E. Bagnato, C. Mariet, E. Garaebiti and B. Pelletier, Ambrym Basaltic Volcano (Vanuatu Arc): Volatile Fluxes, Magma Degassing Rate and Chamber Depth AGU Fall Meeting, VGP31, San Francisco, USA (2009). 
Allibone et al., 2010 R. Allibone, S.J. Cronin, C.T. Douglas, C. Oppenheimer, V.E. Neall and R.B. Stewart, Dental fluorosis linked to degassing on Ambrym volcano, Vanuatu: a novel exposure pathway. Environmental Geochemistry and Health, (2010).

Andres and Kasgnoc, 1998 R.J. Andres and A.D. Kasgnoc, A time-average inventory of subaerial volcanic sulfur emissions. Journal of Geophysical Research, 103 (1998), pp. 25, 251-25, 261.

Baker and Condliffe, 1996 P.E. Baker and E. Condliffe, Compositional variations in submarine volcanic ashes from the vicinity of the Vanuatu Island Arc: a response to ridge-arc collision?. Journal of Volcanology and Geothermal Research, 72 (1996), pp. 225-238.

Bani and Lardy, 2007 P. Bani and M. Lardy, Sulphur dioxide emission rates from Yasur volcano, Vanuatu archipelago. Geophysical Research Letters, 34 (2007), p. L20309.

Bani et al., 2009a P. Bani, J.-L. Join, S.J. Cronin, M. Lardy, I. Rouet and E. Garaebiti, Characteristics of the summit lakes of Ambae volcano and their potential for generating lahars. Natural Hazards Earth System Sciences, 9 (2009), pp. 1471-1478.

Bani et al., 2009b P. Bani, C. Oppenheimer, V.I. Tsanev, S.A. Carn, S.J. Cronin, R. Crimp, D. Charley, M. Lardy and T.R. Robert, Surge in sulphur and halogen degassing from Ambrym volcano, Vanuatu. Bulletin of Volcanology, 7110 (2009), pp. 1159-1168.

Bani et al., 2009c P. Bani, C. Oppenheimer, J.C. Varekamp, T. Quiniou, M. Lardy and S. Carn, Remarkable geochemical changes and degassing at Voui crater lake, Ambae volcano, Vanuatu. Journal of Volcanology and Geothermal Research, 1884 (2009), pp. 347-357.

Bogumil et al., 2003 K. Bogumil, J. Orphal, T. Homann, S. Voigt, P. Spietz, O.C. Fleischmann, A. Vogel, M. Hartmann, H. Kromminga, H. Bovensmann, J. Frerick and J.P. Burrows, Measurements of molecular absorption spectra with the SCIAMACHY preflight model: instrument characterization and reference data for atmospheric remote-sensing in the 230-2380 nm region. Journal of Photochemistry and Photobiology a-Chemistry, 157 (2003), pp. 167-184.

Burne et al., 1988 R.V. Burne, J.-Y. Collot and J. Daniel, Superficial structures and stress regimes of the downgoing plate associated with subduction-collusion in the central New Hebrides arc (Vanuatu), Circum-Pac. Counc. Energy Miner. Resour., Earth Sci. Ser., 8 ,in: H.G. Green, F.L. Wong, Editors, Geology and Offshore Ressources of the Pacific Island Arcs - Vanuatu Region (1988), pp. 357-376.

CarCarn et al., 2008 S.A. CarCarn, A.J. Krueger, N.A. Krotkov, S. Arellano and K. Yang, Daily monitoring of Ecuadorian volcanic degassing from space. Journal of Volcanology and Geothermal Research, 1761 (2008), pp. 141-150.

Chen et al., 1995 J.K. Chen, F.W. Taylor, R.L. Edwards, H. Cheng and G.S. Burr, Recent emerged reef terraces of the Yenkahe resurgent block, Tanna, Vanuatu: implications for volcanic, landslide and tsunami hazards. Journal of Geology, 103 (1995), pp. 577-590. 
Collot et al., 1985 J.-Y. Collot, J. Daniel and R.V. Burne, Recent tectonics associated with the subduction / collision of the d'Entrecasteaux Zone in the central New Hebrides.

Tectonophysics, 112 (1985), pp. 335-356.

Collot et al., 1992 J.-Y. Collot, S. Lallemand, B. Pelletier, J.-P. Eissen, G. Glaçon, M.A. Fisher, H.G. Green, J. Boulin, J. Daniel and M. Monzier, Geology of the d'EntrecasteauxNew Hebrides Arc collision zone: results from a deep submersible survey.

Tectonophysics, 212 (1992), pp. 13-241.

Delmelle et al., 2001 P. Delmelle, J. Stix, C.P.A. Bourque, P. Baxter, J. Garcia-Alvarez and J. Barquero, Dry deposition and heavy acid loading in the vicinity of Masaya volcano, a major sulfur and chlorine source in Nicaragua. Environmental Science \& Technology, 7 (2001), pp. 1289-1293.

Eissen et al., 1991 J.-P. Eissen, C. Blot and R. Louat, Chronology of the historic volcanic activity of the New Hebrides island arc from 1595 to 1991, Rapports Scientifiques et Techniques, Sciences de la Terre, $n^{\circ} 2$ (1991) 66 pp..

Greene and Collot, 1994 H.G. Greene and J.-Y. Collot, Ridge-arc collision: timing and deformation determined by Leg 134 drilling, central New Hebrides island arc, Proc. ODP, Sci. Results, 134 (1994), pp. 609-621.

Halmer et al., 2002 M.M. Halmer, H.-F. Schmincke and H.-F. Graf, The annual volcanic gas input into the atmosphere, in particular into the stratosphere: a global data set for the past 100 years. Journal of Volcanology and Geothermal Research, 115 (2002), pp. 511-528.

Kazahaya et al., 1994 K. Kazahaya, H. Shinohara and G. Saito, Excessive degassing of IzuOshima volcano: magma convection in a conduit. Bulletin of Volcanology, 56 (1994), pp. 207-216.

Kern et al., 2010 C. Kern, F. Kick, P. Lübcke, L. Vogel, M. Wöhrbach and U. Platt, Theoretical description of functionality, applications, and limitations of $\mathrm{SO}_{2}$ cameras for the remote sensing of volcanic plumes. Atmospheric Measurement Techniques, 3 (2010), pp. 733-749.

Kitayama et al., 2010 K. Kitayama, N. Murao and H. Hara, PMF analysis of impacts of SO2 from Miyakejima and Asian Continent on precipitation sulfate in Japan. Atmospheric Environment, 44 (2010), pp. 95-105.

$\underline{\text { Kraus, } 2006}$ S. Kraus, DOASIS - A framework design for DOAS Shaker Verlag, Aachen (2006), p. 184.

Laporte et al., 1998 C. Laporte, L. Briqueu, D. Cluzel and J.-P. Eissen, Isotopic gradient along the New Hebrides arc (Vanuatu, SW Pacific). Collision of the d'Entrecasteaux Zone and heterogeneity of the mantle source. Comptes Rendus de l'Academie des

Sciences, 236 (1998), pp. 101-106.

Lardy and Bani, 2004 M. Lardy and P. Bani Lopevi (Vanuatu) en éruption : forte explosion puis activité fissurale. SVG 33bis (2004), pp. 3-4. 
Levelt et al., 2006 P.F. Levelt, G.H.J. van den Oord, M.R. Dobber, A. Mälkki, H. Visser, P. de Vries, J. Stammes, J. Lundell and H. Saari, The Ozone Monitoring Instrument. IEEE Transactions on Geoscience and Remote Sensing, 445 (2006), pp. 1093-1101.

Louat and Pelletier, 1989 R. Louat and B. Pelletier, Seismotectonics and present-day relative plate motions in the New Hebrides-North Fiji Basin region. Tectonophysics, 197 (1989), pp. $41-55$.

Martin et al., 2010 R.S. Martin, T.A. Mather, D.M. Pyle, J.A. Day, M.L.I. Witt, S.J. Collins and R.G. Hilton, Major and trace element distributions around active volcanic vents determined by analyses of grasses: implications for element cycling and biomonitoring. Bulletin of Volcanology, (2010).

Mather et al., 2006 T.A. Mather, D.M. Pyle, V.I. Tsanev, A.J.S. McGonigle, C. Oppenheimer and A.G. Allen, A reassessment of current volcanic emissions from the Central American arc with specific examples from Nicaragua. Journal of Volcanology and Geothermal Research, 149 (2006), pp. 297-311.

McGonigle et al., 2002 A.J.S. McGonigle, C. Oppenheimer, B. Galle, T.A. Mather and D.M. Pyle, Walking traverse and scanning DOAS measurements of volcanic gas emission rates. Geophysical Research Letter, 2920 (2002), p. 1985.

McGonigle et al., 2004 A.J.S. McGonigle, C. Oppenheimer and V.T. Tsanev, Sulphur dioxide fluxes from Papua New Guinea's volcanoes. Geophysical Research Letters, 31 (2004), p. L08606.

Métrich et al., 2011 N. Métrich, P. Allard, A. Aiuppa, P. Bani, A. Bertagnini, H. Shinohara, F. Parello, A. Di Muro, E. Garaebiti, O. Belhadj and D. Massare, Magma and Volatile Supply to Post-Collapse Volcanism and Block Resurgence in Siwi Caldera (Tanna Island, Vanuatu Arc). Journal of Petrology, 526 (2011), pp. 1077-1105.

Monzier et al., 1997 M. Monzier, C. Robin, J.-P. Eissen and J. Cotton, Geochemistry vs. Seimo-tectonics along the volcanic New Hebrides Central Chain (Southwest Pacific). Journal of Volcanology and Geothermal Research, 78 (1997), pp. 1-29.

Mori et al., 2006 T. Mori, K. Kazahaya, C. Oppenheimer, A.J.S. McGonigle, V. Tsanev, R. Olmos, M. Ohwada and T. Shuto, Sulfur dioxide from the volcanoes of Hokkaido, Japan. Journal of Volcanology and Geothermal Research, 78 (2006), pp. 235-243.

Nemeth et al., 2006 K. Nemeth, S.J. Cronin, D. Charley, M. Harrison and E. Garaebiti, Exploding lakes in Vanuatu - "Surtseyan-style" eruptions witnessed on Ambae Island. Episodes, 29 (2006), pp. 87-92.

Nho et al., 1996 E.-Y. Nho, M.-F. Le Cloarec, B. Ardouin and W.S. Tjetjep, Source strength assessment of volcanic trace elements emitted from the Indonesian arc. Journal of Volcanology and Geothermal Research, 74 121-129 (1996), p. 1996.

Oppenheimer, 2010 C. Oppenheimer, Ultraviolet sensing of volcanic sulfur emissions. Elements, 6 (2010), pp. 87-92. 
Peate et al., 1997 D.W. Peate, J.A. Pearce, C.J. Hawkesworth, H. Colley, C.M.H. Edwards and K. Hirose, Geochemical Variations in Vanuatu Arc Lavas: the Role of Subducted Material and a Variable Mantle Wedge Composition. Journal of Petrology, 3810 (1997), pp. 1331-1358.

Platt and Stutz, 2008 U. Platt and J. Stutz Differential Optical Absorption Spectroscopy: principles and applications, XV 597, Springer, Heidelberg (2008), p. 272.

Pontoise et al., 1994 B. Pontoise, P. Charvis and M. Gérard, Sedimentary and crustral structure of the North Basin from seismic refraction data. ODP. Scientific

Results, 134 (1994), pp. 549-563.

Stoiber et al., 1983 R.E. Stoiber, Jr Malinconico and S.N. Williams, Use of the correlation spectrometer at volcanoes, H. Tazieff, J.C. Sabroux, Editors, Forecasting Volcanic Events, Elsevier, New York (1983), pp. 425-444.

Taylor et al., 1994 F.W. Taylor, T.M. Quinn, C.G. Gallup and R.L. Edwards, Quaternary plate convergence rates at the New Hebrides island arc from chronostratigraphy of Bougain ville Guyot (Site 831), Proc. ODP, Sci. Results, 134 (1994), pp. 47-57.

Tsanev, 2008 V.I. Tsanev, A collection of JScripts for retrieval of gas column amounts using DOAS methodology, (2008), Available from :

http://www.geog.cam.ac.uk/research/projects/doasretrieval/.

Turner et al., 1999 S.P. Turner, D.W. Peate, C.J. Hawkesworth, S.M. Eggins and A.J.

Crawford, Two mantle domains and the time scales of fluid transfer beneath the Vanuatu arc.

Geology, 2711 (1999), pp. 963-966.

Voigt et al., 2001 S. Voigt, J. Orphal, K. Bogumil and J.P. Burrows, The Temperature Dependence (203-293 K) of the Absorption Cross-Sections of O3 in the 230-850 nm region Measured by Fourier-Transform Spectroscopy. Journal of Photochemistry and Photobiology A: Chemistry, 143 (2001), pp. 1-9.

Yang et al., 2007 K. Yang, N.A. Krotkov, A.J. Krueger, S.A. Carn, P.K. Bhartia and P.F. Levelt, Retrieval of large volcanic $\mathrm{SO}_{2}$ columns from the Aura Ozone Monitoring Instrument: comparison and limitations. Journal of Geophysical Research, 112 (2007), p. D24S43 